\title{
IMPLEMENTASI PERATURAN DAERAH KOTA KUPANG NOMOR 15 TAHUN 2011 TENTANG RETRIBUSI PELAYANAN PARKIR DI TEPI JALAN UMUM
}

\author{
Harlan Evan Kapioru \\ Pasca Sarjana Ilmu Hukum Universitas Nusa Cendana - NTT \\ Jl. Perintis Kemerdekaan 1, Oebufu Kupang \\ alanevankapioru@gmail.com
}

\begin{abstract}
Abstrak: Implementasi Peraturan Daerah Kota Kupang Nomor 15 Tahun 2011 tentang Retribusi Pelayanan Parkir di Tepi Jalan Umum. Sehubungan dengan adanya perbedaan potensi parkir dengan realisasi penerimaan saat operasional dilapangan Penelitian ini dilaksanakan untuk menjawab pertanyaan; Bagaimanakah Kontribusi Retribusi Pelayanan Parkir di Tepi Jalan Umum dalam mendukung peningkatan Pendapatan Asli Daerah dalam 5 (lima) tahun terakhir, dan Faktor - Faktor apakah yang mempengaruhi rendahnya kontribusi Retribusi Pelayanan Parkir di Tepi Jalan Umum terhadap penerimaan Pendapatan Asli Daerah. Temuan penelitian menperlihatkan bahwa, data perkembangan kontribusi retribusi parkir di tepi jalan umum terhadap total penerimaan PAD, periode tahun 2009 sebesar 1,62 \% dan menurun terus menjadi $1,52 \%$ tahun 2013. Penerimaan retribusi daerah, pada tahun 2009 sebesar 4,17 \% dan menurun menjadi 3,08 \% pada tahun 2013. Selanjutnya penerimaan retribusi jasa umum sebesar 1,66\% tahun 2009 dan menurun hingga tahun 2012 dan tahun 2013 meningkat menjadi 1,70\%. Secara umum dapat disimpulkan bahwa, kontribusi retribusi parkir di tepi jalan umum belum menunjukkan peranan yang signifikan terhadap pembentukkan PAD Kota Kupang. Faktor - faktor yang menyebabkan kecilnya angka penerimaan retribusi parkir di tepi jalan umum adalah; Faktor sistem managemen penanganan parkir dan faktor sistem pemungutan retribusi parkir yang belum berjalan secara baik. Berdasarkan pendekatan ROCCIPI ditemukan perilaku bermasalah terjadi pada semua pemegang peran.
\end{abstract}

Kata Kunci : Implementasi, Perda No. 15 Tahun 2011 tentang Retribusi Pelayanan Parkir di tepi Jalan Umum, SPK, PAD Kota Kupang, Faktor Penyebab Rendahnya Retribusi Parkir di tepi Jalan Umum dan ROCCIPI.

Abstract: The Implementation of Local Regulation No. 15/2011 on the edge of the Service Levy at Public Road Parking. In connection with the difference in potential parking revenue realization when operational field research was conducted to answer the question: How Service Levy Contributions Parking Public Road in supporting the original income within 5 (five) years, Factors - What factors affect the low contribution Service Levy Public Roadside Parking on receipt original income. The findings of the study showed that, the data development contribution levy parking on the edge of the public road to total revenue receipts, the period of 2009 amounted to $1.62 \%$ and continues to decline to $1.52 \%$ in 2013. Acceptance of retribution, in 2009 amounted to $4.17 \%$ and decreased to $3.08 \%$ in 2013. The next general acceptance services levy of $1.66 \%$ in 2009 and declined through 2012 and in 2013 increased to $1.70 \%$. in general it can be concluded that the contribution of roadside parking fees in general have not shown a significant role towards the formation of PAD Kupang. Factors - factors that led to the low number of reception roadside parking fees are common; Factor management systems handling park and parking fee collection system factors that have not been run well. Based approach ROCCIPI found problematic behavior 


\section{JURNAL NOMINAL / VOLUME III NOMOR 1 / TAHUN 2014}

occurs on all stakeholders. This suggests that the implementation of Regulation No. 15 in 2011 is not effective.

Keywords: Implementation, Regulation No. 15 of 2011 on the edge of the Service Levy at Public Road Parking, SPK, PAD Kupang City, Low Causes Parking Levy Public Roads and ROC

\section{PENDAHULUAN}

\section{Latar Belakang Masalah}

Penyelenggaraan fungsi pemerintahan daerah akan terlaksana secara optimal apabila adanya sumber penerimaan yang cukup pada daerah, dengan mengacu kepada Undang - Undang tentang Perimbangan Keuangan antara Pemerintah Pusat dan Pemerintah Daerah, dimana besarnya disesuaikan dan diselaraskan dengan pembagian kewenangan antara pemerintah pusat dan daerah. Semua sumber keuangan yang melekat pada setiap urusan pemerintah yang diserahkan pada daerah menjadi sumber keuangan daerah. Daerah diberikan hak mendapatkan sumber keuangan yang antara lain berupa : kepastian tersedianya persediaan pendanaan dan pemerintahan sesuai dengan urusan pemerintah yang disertakan; kewenangan memungut dan mendayagunakan pajak dan retribusi daerah dan hak untuk mendapatkan bagi hasil dari sumber - sumber daya nasional yang berada di daerah dan dana perimbangan lainya; hak untuk mengelola kekayaan daerah dan mendapatkan sumber - sumber pendapatan lain yang sah. Dengan pengaturan tersebut, dalam hal ini pemerintah menetapkan prinsip "uang mengikuti fungsi". 1

Realitas Kota Kupang dalam menjalani otonomi daerah selama ini menunjukkan bahwa, dari segi keuangan (fiscal), ketergantungan terhadap dana perimbangan yang berasal dari pemerintah pusat sangatlah besar. PAD Kota Kupang lima tahun terakhir (2007 - 2011) menunjukkan peningkatan secara konstan, tahun 2007 sebesar Rp. 30.659.877.526 naik menjadi Rp. 47.702.927.428 tahun 2011 atau mengalami kenaikkan rata - rata $13,90 \%$ pertahun. Sumber PAD yang dominan pada tahun 2007 adalah penerimaan lain - lain yang sah, kemudian bergeser ke pajak daerah pada tahun 2011. Sumber PAD yang terkecil adalah Retribusi Daerah dan Lain Lain Pendapatan Yang Sah. Peran Retribusi Daerah terhadap total PAD menurun dari 24,77\% (2007) menjadi 23,62\% (2011). Sementara peranan pendapatan lain - lain

\footnotetext{
1 Nurlan Darise, AK,pengelolaan Keuangan Daerah, dalam Dokumen Balitbang kajian hasil Penelitian, evaluasi penerimaan pendapatan asli daerah (PAD) bersumber dari Pajak dan Retribusi Daerah Pemerintah Kota Kupang, 2013, hlm. 6
} 


\section{JURNAL NOMINAL / VOLUME III NOMOR 1 / TAHUN 2014}

yang sah terhadap total PAD menurun dari $39,33 \%$ (2007) menjadi $13,04 \%$ (2011). ${ }^{2}$

Pendapatan Asli Daerah (PAD) berasal dari 4 (empat) sumber, yaitu : Pajak Daerah, Retribusi Daerah, Penerimaan dari pengelolaan aset daerah yang dipisahkan dan Penerimaan lain lain. Dari ke - empat sumber tersebut, retribusi daerah menjadi sangat penting untuk menunjukkan kemampuan pemerintah dalam memberi layanan yang baik untuk meningkatkan aktivitas ekonomi masyarakat. Peranan retribusi daerah yang besar dalam pembentukan PAD mencerminkan kemampuan pemerintah untuk melayani semakin baik. Formasi PAD Kota Kupang menunjukkan bahwa, peranan pajak daerah semakin meningkat sementara retribusi daerah mengalami penurunan secara relatif terhadap total PAD. Fakta ini menjadi alasan utama untuk mengkaji lebih lanjut bagaimana meningkatkan penerimaan retribusi daerah terhadap PAD di waktu mendatang.

Salah satu sumber penerimaan daerah yang perlu mendapat perhatian adalah Retribusi Pelayanan Parkir Di Tepi Jalan Umum, yang merupakan bagian dari retribusi umum. Peraturan Daerah (Perda) Nomor 15 tahun 2011 tentang Retribusi Pelayanan Parkir Di Tepi Jalan Umum

2 Litbang Kota Kupang; Kajian Potensi Pendapatan Asli Daerah Melalui Retribusi Pasar Kota

Kupang, Tahun 2012, hlm . 26-27 menjadi dasar hukum pelaksanakan pemungutan retribusi pelayanan parkir dimasyarakat. Kebijakan pengelolaan perpakiran di Kota Kupang menjadi tanggung jawab Satuan Kerja Perangkat Daerah (SKPD) Perhubungan. Teknis pelaksanaan pemungutan retribusi parkir dilapangan SKPD ini bermitra dengan pihak kedua (orang pribadi dan atau badan hukum). Pihak kedua (Pengelola Parkir) diberikan mandat (tanggung jawab) menangani pelayanan parkir kendaraan bermotor di tepi jalan umum. Penunjukkan pihak kedua dalam menangani pungutan retribusi di setiap lokasi perpakiran, menggunakan sistem tender (penawaran harga). Setiap pemenang tender ditindaklanjuti dengan Surat Perjanjian Kerja (SPK) dengan masa berlaku selama satu tahun (01 Januari - 31 Desember).

Berdasarkan hasil observasi diketahui bahwa, Lokasi parkir di wilayah Kota Kupang hampir semuanya memanfaatkan badan jalan, padahal kondisi Jalan - jalan dalam Kota Kupang tidak semuanya memiliki lebar yang cukup untuk dijadikan lokasi parkir kendaraan, sehingga telah menimbulkan kemacetan arus lalu lintas terutama pada lokasi pusat perdagangan Jalan Sudirman (Kuanino) hingga Jalan Mohammad Hatta (Fontein), terus ke Jalan Ahmad Yani (Oeba - Merdeka - Oebobo) dan terus ke daerah Pertokoan di Jalan Siliwangi pada jam - jam sibuk pagi, siang 


\section{JURNAL NOMINAL / VOLUME III NOMOR 1 / TAHUN 2014}

dan atau sore hingga malam hari. Kemacetan arus lalu lintas tersebut dipicu oleh perilaku bermasalah dari para pengendara yang kurang atau tidak mentaati rambu - rambu lalulintas; perilaku bermasalah dari pengelola parkir beserta juru parkir yang kurang bertanggung jawab dalam menjalankan perannya; serta perilaku bermasalah dari lembaga pelaksana peraturan yang belum optimal menjalankan tugas dan fungsinya secara baik.

Berdasarkan permasalahan yang terjadi di lapangan, maka perlu dilakukan evaluasi implementasi Perda Nomor 15 tahun 2011 agar dapat dilakukan penyempurnaan berdasarkan perkembangan yang telah terjadi. Dalam kajian ini, peneliti berupaya menjawab pertanyaan berikut :

1. Bagaimanakah kontribusi Retribusi Pelayanan Parkir Di Tepi Jalan Umum dalam mendukung Peningkatan Pendapatan Asli Daerah dalam 5 (lima) tahun terakhir?

2. Faktor - faktor apakah yang mempengaruhi rendahnya kontribusi Retribusi Pelayanan Parkir Di Tepi Jalan $a$ Umum terhadap penerimaan Pendapatan Asli Daerah

b. format kebijakan (the form of the policy

\section{Kerangka Teori}

\section{Merilee S. Grindle mengatakan}

c. Reputasi actor (the reputation of the bahwa keberhasilan implementasi dipengaruhi oleh dua variabel besar yakni isi kebijakan ( content of policy) dan message)

lingkungan implementasi (context of implementation). variabel isi kebijakan ini mencakup : (1) sejauhmana kepentingan kelompok sasaran atau target groups termuat dalam isi kebijakan; (2) jenis manfaat yang diterima oleh target group, (3) sejauhmana perubahan yang diinginkan dari sebuah kebijakan.; (4) apakah letak sebuah program sudah tepat. (5) apakah sebuah kebijakan telah menyebutkan implementornya dengan rinci ; dan (6) apakah sebuah program didukung oleh sumberdaya yang memadai. Sedangkan variabel lingkungan kebijakan mencakup : (1) seberapa besar kekuasaan, kepentingan, dan strategi yang dimiliki oleh para aktor yang terlibat dalam implementasi kebijakan; (2) karakteristik institusi dan rejim yang sedang berkuasa; (3) tingkat kepatuhan dan responsivitas kelompok sasaran ${ }^{3}$

Kebijakan diasumsikan sebagai suatu "pesan" dari pemerintah federal (pusat) kepada pemerintah daerah. Keberhasilan implementasi pesan tersebut sangat dipengaruhi oleh 3 hal pokok :

isi kebijakan (the content of the policy message)

communicators)

\footnotetext{
${ }^{3}$ Merilee S. Grindle 1980, dalam AG Subarsono, Analisis Kebijakan Publik, Op.Cit. hlm. 93
} 


\section{JURNAL NOMINAL / VOLUME III NOMOR 1 / TAHUN 2014}

Isi kebijakan meliputi sumberdaya, manfaat kebijakan, serta keterlibatan publik. Format kebijakan tersendiri dari kejelasan kebijakan (policy clarity), konsistensi kebijakan (policy consistency), frequency serta penerimaan isi kebijakan (receipt of message). Sedangkan reputation of communicator terdiri dari legitimasi dan kredibilitas aktor - aktor pemerintah daerah. Ada empat faktor yang mempengaruhi kinerja implementasi, yaitu :

a. Kondisi lingkungan (environmental conditions)

b. Hubungan antar organisasi (inter organizational relationship)

c. Sumberdaya (resources)

d. Karakter institusi implementor (characteristic implementing agencies) ${ }^{4}$

Implementasi Perda Nomor 15 tahun 2011, telah mengakibatkan timbulnya berbagai masalah sosial. Masalah sosial harus dilihat sebagai suatu rangkaian perilaku berulang ( $a$ set of repetitive behavior) yang menimbulkan dampak negatif bagi manusia dan kondisi fisik. Selanjutnya, dari pengertian tersebut, kita memperoleh suatu rumusan pertanyaan kunci untuk menentukan masalah sosial yaitu : (1) Apakah masalah tersebut terjadi berulang - ulang atau sekali saja ?; (2) Apakah masalah tersebut mempunyai

${ }^{4}$ Ibid, hlm .89-90 dampak negatif yang dapat dirasakan ?; (3) Apakah masalah tersebut dibentuk oleh sekumpulan perilaku atau hanya satu perilaku tunggal ? Jika jawaban menunjukan serangkaian perilaku yang menimbulkan dampak negatif terjadi berulang - ulang, kondisi tersebut adalah masalah sosial.

Langkah pertama, kita akan menyelami sampai pada pemahaman tentang masalah sosial yang ingin dipecahkan oleh rancangan peraturan. Untuk sampai pada pemahaman tersebut, kita perlu menempuh 2 tahapan, yaitu : Pertama : Membuktikan Dampak Negatif Masalah Sosial, dilakukan dengan pembuktian gejala. Masalah sosial lebih mudah dikenali dari gejalanya. Gejala adalah wujud nyata masalah sosial. Dampaknya dapat dirasakan, gejala berisikan hal - hal nyata, bukan hal - hal konseptual atau abstrak. Pemaparan gejala masalah sosial menjadi penting juga karena akan digunakan untuk meyakinkan pemerintah, lembaga perwakilan, serta masyarakat. tersebut memang benar - benar diperlukan untuk memecahkan suatu masalah sosial.

Kedua : Membuktikan perilaku bermasalah yang turut menimbulkan masalah sosial. Karena rancangan peraturan hanya ditujukkan bagi perilaku, diperlukan pembuktian tentang perilaku apa dan siapa pelakunya ( Whose and What behavior) yang turut menimbulkan masalah sosial. 


\section{JURNAL NOMINAL / VOLUME III NOMOR 1 / TAHUN 2014}

Perilaku tersebut dalam MPM dinamakan sebagai perilaku bermasalah. Dengan kata lain, tahap ini merupakan pembuktian perilaku bermasalah. MPM mengelompokkan pihak - pihak yang perilakunya terkait dengan masalah sosial akan ditangani oleh rancangan peraturan. Pihak - pihak terkait itu terdiri dari : (1) Aktor (Role Occupant); (2) Pelaksana Peraturan ( Implementing Agent). Pelaksana peraturan adalah pihak - pihak yang diberi kewenangan oleh peraturan untuk memastikan bahwa aktor berperilaku sesuai peraturan. Sering perilaku bermasalah juga dilakukan oleh pelaksana peraturan. Dalam keadaan ini, pelaksana peraturan dapat dilakukan sebagai aktor. Fakta empirik harus menjadi dasar dalam menentukan perilaku apa dan siapa pelakunya yang turut menimbulkan masalah sosial. Kita bisa menggunakan sumber data yang sama ketika menggali gejala. ${ }^{5}$

Pada langkah kedua ini kita akan menggali berbagai penyebab dan perilaku bermasalah yang telah dikenali dalam langkah pertama. Mengapa mesti menemukan penyebab ? peraturan yang berhasil adalah peraturan yang mampu mengubah atau menghilangkan berbagai penyebab perilaku bermasalah. Artinya, perlu mengetahui berbagai penyebab terjadinya perilaku bermasalah agar dapat

\footnotetext{
${ }^{5}$ Id., hlm 89 - 92
}

menyusun pemecahannya di dalam rancangan peraturan.

Suatu rumusan yang perlu kita ingat dalam menemukan penyebab perilaku bermasalah adalah : satu perilaku penyebab bermasalah selalu di timbulkan oleh banyak penyebab. Apa yang perlu kita lakukan untuk memudahkan, kita perlu merumuskan berbagai hipotesis tentang sebab - sebab terjadinya perilaku bermasalah. Fakta empirik dan dijelaskan secara logis kedalam hubungan sebab akibat. Karena perilaku bermasalah ditimbulkan oleh banyak penyebab, bagaimana cara mendapatkan hipotesis - hipotesis tentang berbagai penyebab perilaku bermasalah tersebut ? untuk menghimpun dan menjelaskan berbagai hipotesis yang menjadi penyebab perilaku bermasalah, MPM menggunakan suatu alat yang bernama agenda ROCCIPI merupakan singkatan dari 7 (tujuh) kategori pokok yang penyusunanya, yaitu : 1. Rule (Peraturan); 2. Opportunity (Kemampuan); 3. Capacity (Kemampuan ); 4. Comunication (Komunikasi); 5. Interest (Kepentingan); 6. Process (Proses); 7. Ideology (Nilai dan sikap).

Dalam kaitan dengan implementasi kebijakan Perda Parkir Nomor 15 tahun 2011, diharapkan dapat berjalan secara efektif sebagaimana yang diharapkan dari perda tersebut. Soerjono Soekanto berpendapat tentang pengaruh hukum "Salah satu fungsi hukum baik sebagai 


\section{JURNAL NOMINAL / VOLUME III NOMOR 1 / TAHUN 2014}

kaidah maupun sebagai sikap tindak atau perilaku teratur adalah membimbing perilaku manusia. Masalah pengaruh hukum tidak hanya terbatas pada timbulnya ketaatan atau kepatuhan pada hukum tapi mencakup efek total dari hukum terhadap sikap tindak atau perilaku baik yang bersifat positif maupun negatif ${ }^{6}$

Ketaatan seseorang bersikap tindak atau berperilaku sesuai dengan harapan pembentuk undang - undang bahwa pengaruh hukum terhadap sikap tindak atau perilaku, dapat diklasifikasikan sebagai ketaatan (compliance), ketidaktaatan atau penyimpangan (deviance) dan pengelakan (evasion). Konsep - konsep ketaatan, ketidaktaatan atau penyimpangan dan pengelakan sebenarnya berkaitan dengan hukum yang berisikan larangan atau suruhan. Bilamana hukum tersebut berisikan kebolehan, perlu dipergunakan konsep konsep lain, yakni penggunaan (use), tidak menggunakan (nonuse) dan penyalahgunaan (misuse); hal tersebut adalah lazim dalam bidang hukum perikatan.

Efektivitas penegakan hukum amat berkaitan erat dengan efektivitas hukum. Agar hukum itu efektif, maka diperlukan aparat penegak hukum untuk menegakkan sanksi tersebut. Suatu sanksi dapat diaktualisasikan kepada masyarakat dalam

\footnotetext{
${ }^{6}$ Soerjono Soekanto, Pokok - Pokok Sosiologi Hukum, 2012, Jakarta, Rajawali Pers, PT

Raja Grafindo Persada, hlm.121
}

bentuk ketaatan (compliance), dengan kondisi tersebut menunjukkan adanya indikator bahwa hukum tersebut adalah efektif.

Parkir di tepi jalan umum meruapakan salah satu sumber penerimaan retribusi yang turut berkontribusi terhadap Pendapatan Asli Daerah yang merupakan pendapatan daerah yang bertujuan untuk memberikan keleluasan kepada daerah dalam menggali pendanaan dalam melaksanakan Otonomi Daerah sebagai perwujudan asas desentralisasi yang bersumber dari hasil pajak daerah, hasil retribusi daerah, hasil pengelolaan kekayaan daerah yang dipisahkan, dan lain - lain pendapatan asli daerah yang sah. Lain - lain pendapatan Asli Daerah yang sah adalah pendapatan yang diterima seperti pendapatan hibah, dana darurat, dana bagi hasil dari provinsi dan pemerintah daerah lain.

Undang - Undang Nomor 28 tahun 2009 mendefinisikan retribusi daerah / retribusi yaitu pungutan daerah sebagai pembayaran atas jasa / pemberian izin tertentu yang khusus disediakan dan atau diberikan oleh pemerintah untuk kepentingan pribadi atau badan. Retribusi pada dasarnya merupakan harga yang dibayar seseorang karena mendapatkan manfaat dari layanan atau sarana dan prasarana yang disediakan 


\section{JURNAL NOMINAL / VOLUME III NOMOR 1 / TAHUN 2014}

pemerintah. ${ }^{7}$ Halim berpendapat bahwa retribusi adalah pungutan yang dilakukan pemerintah sebagai akibat adanya kontraprestasi yang diberikan pemerintah daerah, atau pembayaran tersebut didasarkan atas prestasi atau pelayanan yang diberikan pemerintah daerah yang langsung dinikmati secara perseorangan oleh warga masyarakat dan pelaksanaannya didasarkan atas peraturan yang berlaku. ${ }^{8}$

Berdasarkan uraian di atas, maka karateristik retribusi adalah : (1) retribusi dipungut berdasarkan peraturan - peraturan yang dikeluarkan oleh Pemerintah Daerah yang berlaku umum, (2) dalam retribusi, hubungan antara prestasi yang dilakukan (dalam bentuk pembayaran) dengan kontraprestasi itu bersifat langsung, dimana pembayaran retribusi justru menghendaki adanya jasa timbal balik langsung dari pemerintah; contohnya pembayaran air minum, telepon, listrik, pasar dan sebagainya, (3) hasil penerimaan retribusi digunakan untuk pelayanan umum terkait dengan retribusi yang bersangkutan, (4) pelaksanaan retribusi mudah ditetapkan dalam hal pengenaan tarif dan pemungutan serta bersifat memaksa. Prinsip utama yang

\footnotetext{
7 Undang - Undang Nomor 28 Tahun 2009 tentang Pajak dan Retribusi Daerah

${ }^{8}$ Halim 2004 dalam Konsepsi Retribusi Daerah, dalam balitbang, Kajian Pendapatan Asli

Daerah Melalui Potensi Retribusi Parkir Kota Kupang, 2013, Op Cit. hlm. 6
}

terkandung dibalik ciri - ciri retribusi di atas adalah keadilan dan kemanfaatan. ${ }^{9}$

\section{METODE PENELITIAN}

Penelitian ini menggunakan pendekatan empiris dan yuridis normatif. Pendekatan empiris dilakukan untuk mendapatkan data time series perkembangan PAD Kota Kupang tahun 2009 - 2013. Sedangkan kajian yuridis normatif dipusatkan pada dokumen Perda Nomor 15 Tahun 2011 tentang Retribusi Pelayanan Parkir di Tepi Jalan Umum.Penelitian ini bersifat kualitatif dengan jumlah informan dan responden sebagai berikut; Pejabat Bidang Penataan dan Pendataan Perhubungan, Pengelola parkir satu orang, Juru parkir sejumlah tiga orang, Pengguna jasa parkir 4 orang terdiri dari pengendara roda dua dan roda empat. Pengumpulan data menggunakan metode observasi (pengamatan) langsung dilapangan terkait dengan masalah yang diteliti. Observasi dilakukan pada pusat pusat keramaian di sekitar Jalan Soedirman, Jalan Mohammad Hata, Jalan Siliwangi dan beberapa bagian jalan kolektor lainnya. Selain observasi juga dilakukan Wawancara langsung dengan responden mempergunakan daftar pertanyaan yang disiapkan sebelumnya. Metode Focus Group Discusson (FGD) digunakan dalam pertemuan dan diskusi dengan Petugas

${ }^{9} I d .$, hlm.8 


\section{JURNAL NOMINAL / VOLUME III NOMOR 1 / TAHUN 2014}

Parkir. Analisa data untuk kedua rumusan masalah diatas di analisis secara deskriptif, dan khusus faktor yang berhubungan dengan perilaku bermasalah para aktor yang berdampak pada rendahnya kontribusi retribusi parkir di tepi jalan umum dalam mendukung PAD Kota Kupang di gunakan Metode ROCCIPI (Rule, Opportunity, Communication, Interest, Procces dan Ideology)

\section{HASIL PENELITIAN DAN} PEMBAHASAN

Kontribusi Retribusi Parkir Di Tepi Jalan Umum Dalam Mendukung Pendapatan Asli Daerah Kota Kupang Periode Lima Tahun Terakhir (2009 2013)

Penyelenggaraan fungsi pemerintahan daerah akan terlaksana secara optimal apabila adanya sumber penerimaan yang cukup pada daerah, dengan mengacu kepada Undang - Undang tentang Perimbangan Keuangan antara Pemerintah Pusat dan Pemerintah Daerah, dimana besarnya disesuaikan dan diselaraskan dengan pembagian kewenangan antara pemerintah pusat dan daerah. Semua sumber keuangan yang melekat pada setiap urusan pemerintah yang diserahkan pada daerah menjadi sumber keuangan daerah. Daerah diberikan hak mendapatkan sumber keuangan yang antara lain berupa : kepastian tersedianya persediaan pendanaan dan pemerintahan sesuai dengan urusan pemerintah yang disertakan; kewenangan memungut dan mendayagunakan pajak dan retribusi daerah dan hak untuk mendapatkan bagi hasil dari sumber - sumber daya nasional yang berada di daerah dan dana perimbangan lainya; hak untuk mengelola kekayaan daerah dan mendapatkan sumber - sumber pendapatan lain yang sah. ${ }^{10}$

Bagaimana gambaran Pendapatan Asli Daerah pemerintah Kota Kupang dalam kurun waktu lima tahun terakhir (2009 2013). Berdasarkan pengumpulan data sekunder pada Dinas Pendapatan Daerah Kota Kupang, diketahui bahwa perkembangan penerimaan PAD menurut sumber - sumber PAD di Kota Kupang tahun 2009 - 2013 dapat dilihat pada tabel 1.1.

Data pada tabel tersebut menunjukkan bahwa PAD Kota Kupang dalam Lima tahun terakhir (2009 - 2013) menunjukkan peningkatan secara konstan, yaitu naik dari Rp. 36.204.733.167,02 (2009) menjadi Rp. 80.753.000.000,- (2013), atau mengalami kenaikkan rata - rata $44,61 \%$ per tahun. Data tersebut juga menunjukkan bahwa, peranan dari masing - masing sumber PAD mengalami perubahan sepanjang lima tahun. Pada tahun 2009, sumber PAD yang

\footnotetext{
${ }^{10}$ Nurlan Darise, AK, pengelolaan Keuangan Daerah, dalam Dokumen Balitbang kajian hasil Penelitian, evaluasi penerimaan pendapatan asli daerah (PAD) bersumber dari Pajak dan

Retribusi Daerah Pemerintah Kota Kupang, 2013,
} hlm. 6 


\section{JURNAL NOMINAL / VOLUME III NOMOR 1 / TAHUN 2014}

dominan adalah penerimaan lain - lain yang sah, kemudian bergeser ke pajak daerah pada tahun 2012 dan 2013. Sumber PAD yang terkecil peranannya adalah retribusi daerah (2009 - 2011), namun pada tahun 2012 - 2013 sumber PAD yang terkecil bergeser kepenerimaan lain - lain yang sah.

Tabel 1.

Perkembangan Pendapatan Asli Daerah (PAD) Pemerintah Kota Kupang Tahun 2009 - 2013

\begin{tabular}{|c|c|c|c|c|c|}
\hline $\begin{array}{l}\text { Sumber Sumber } \\
\text { PAD }\end{array}$ & 2009 & 2010 & 2011 & 2012 & 2013 \\
\hline Pajak Daerah & 11.977 .785 .476 & 13.247 .651 .835 & $22.200 .583 .682,60$ & 31.569 .104 .259 & 41.146 .449 .346 \\
\hline Retribusi Daerah & 9.323.675.310 & 10.237.262.522 & 11.267.458.193 & 17.403.248.035 & 21.593.942.764 \\
\hline $\begin{array}{l}\text { Pengelolaan Aset } \\
\text { Daerah Yang Di } \\
\text { pisahkan }\end{array}$ & 4.515.252.840 & 5.940 .394 .702 & 8.015.299.050,51 & 9.507.134.169,71 & 9.860 .152 .470 \\
\hline $\begin{array}{l}\text { Penerimaan Lain - } \\
\text { Lain Yang Sah }\end{array}$ & 10.387.019.541 & 7.403.582.395,35 & 6.219.586.502,09 & 7.588.600.737,93 & 8.154.927.408 \\
\hline Tot a 1 & $\begin{array}{c}36.204 .733 .167,0 \\
2\end{array}$ & 36.828.891.454,35 & 47.702.927.427,60 & 66.068.087.201,64 & 80.755.471.988 \\
\hline
\end{tabular}

Sumber : Buku APBD Kota Kupang 2009 - 2013

Berdasarkan informasi Kajian Pendapatan dan Belanja Publik yang dilakukan Pemerintah Provinsi NTT bekerjasama dengan AuSAid, menunjukkan bahwa, pada semua pemerintah Kabupaten/Kota di NTT, persentase penerimaan yang berasal dari dana perimbangan mencapai 90\%. Hal ini menunjukkan bahwa penggalian sumber pendapatan berdasarkan kewenangan otonomi yang di miliki pemerintah Kota Kupang belumlah memadai

\section{Perkembangan Retribusi Daerah} Menurut Sumber-Sumber Retribusi Tahun 2009 -2013

Undang - Undang Nomor 28 tahun 2009 mendefinisikan retribusi daerah / retribusi yaitu pungutan daerah sebagai pembayaran atas jasa / pemberian izin tertentu yang khusus disediakan dan atau diberikan oleh pemerintah untuk kepentingan pribadi atau badan. Retribusi pada dasarnya merupakan harga yang dibayar seseorang karena mendapatkan manfaat dari layanan atau sarana dan prasarana yang disediakan pemerintah. ${ }^{11}$ Halim berpendapat bahwa retribusi adalah pungutan yang dilakukan pemerintah sebagai akibat adanya kontraprestasi yang diberikan pemerintah daerah, atau pembayaran tersebut didasarkan atas prestasi atau pelayanan yang diberikan pemerintah daerah yang langsung dinikmati secara perseorangan oleh warga masyarakat dan pelaksanaannya didasarkan atas peraturan yang berlaku. ${ }^{12}$

Bagaimana gambaran perkembangan retribusi daerah pemerintah Kota Kupang

\footnotetext{
11 Undang - Undang Nomor 28 Tahun 2009 tentang Pajak dan Retribusi Daerah ${ }^{12}$ Halim 2004 dalam Konsepsi Retribusi Daerah, dalam balitbang, Kajian Pendapatan Asli

Daerah Melalui Potensi Retribusi Parkir Kota Kupang, 2013, Op Cit. hlm. 6
} 


\section{JURNAL NOMINAL / VOLUME III NOMOR 1 / TAHUN 2014}

dalam kurun waktu lima tahun terakhir (2009 - 2013). Berdasarkan pengumpulan data sekunder pada Dinas Pendapatan Daerah Kota Kupang, diketahui bahwa perkembangan penerimaan retribusi daerah adalah sebagai berikut : Retribusi daerah
Kota Kupang mengalami peningkatan secara konstan, dari Rp. 9.323.675.31 (2009) menjadi Rp.21.593.942.764 (2013) atau rata - rata meningkat sebesar 46,32\% per tahun. Data selengkapnya di lihat pada tabel berikut :

Tabel 2

Perkembangan Penerimaan Retribusi Daerah Kota Kupang Menurut Sumbernya Tahun 2009 $-2013$

\begin{tabular}{|c|c|c|c|c|c|}
\hline $\begin{array}{l}\text { RETRIBUSI } \\
\text { DAERAH } \\
\end{array}$ & 2009 & 2010 & 2011 & 2012 & 2013 \\
\hline $\begin{array}{l}\text { Retribusi Jasa } \\
\text { Umum }\end{array}$ & 3.716 .988 .800 & 4.214.111.000 & 4.367.593.109 & 8.353.541.085 & 11.889 .952 .214 \\
\hline $\begin{array}{l}\text { Retribusi Jasa } \\
\text { Usaha }\end{array}$ & 1.548.605.510 & 887.076 .780 & 845.954 .340 & 1.483.571.150 & 1.621 .881 .550 \\
\hline $\begin{array}{l}\text { Retribusi } \\
\text { Perizinan } \\
\text { Tertentu }\end{array}$ & 4.058.081.000 & 5.136.074.742 & 6.053.910.744 & 7.566.135.800 & 8.082 .109 .000 \\
\hline Total & 9.323.675.31 & 10.237 .262 .522 & 11.267.458.193 & 17.403.248.035 & 21.593.942.764 \\
\hline
\end{tabular}

Sumber : Buku APBD Pemerintah Kota Kupang 2009 - 2013 (Data diolah)

Data pada tabel di atas menunjukkan bahwa, peranan dari masing - masing sumber retribusi daerah mengalami perubahan sepanjang lima tahun terakhir. Pada tahun 2009 - 2011 sumber retribusi daerah yang dominan adalah retribusi perizinan tertentu, kemudian bergeser ke retribusi jasa umum pada tahun 2012 dan 2013.

Ratribusi Jasa Umum dalam dua tahun terakhir (2012 - 2013) sebagai penyumbang terbesar dalam pembentukan retribusi daerah. Sumber Retribusi Jasa Umum terdiri dari : (1) retribusi pelayanan kesehatan, (2) retribusi pelayanan persampahan/ kebersihan, (3) retribusi pengganti biaya KTP dan Akta Catatan Sipil, (4) retribusi pelayanan parkir di tepi jalan umum, (5) retribusi pengujian kendaraan bermotor, (6) retribusi PHB/Askes, dan (7) retribusi izin usaha jasa konstruksi.

$$
\text { Peranan masing - masing sumber }
$$
retribusi jasa umum, ditunjukkan pada tabel berikut : 


\section{JURNAL NOMINAL / VOLUME III NOMOR 1 / TAHUN 2014}

Tabel 3

Peranan Sumber - Sumber Penerimaan Retribusi Jasa Umum Pemerintah Kota Kupang

Tahun $2009-2013$

\begin{tabular}{|c|c|c|c|c|c|}
\hline $\begin{array}{l}\text { RETRIBUSI } \\
\text { JASA UMUM }\end{array}$ & 2009 & 2010 & 2011 & 2012 & 2013 \\
\hline $\begin{array}{l}\text { Pelayanan } \\
\text { Kesehatan }\end{array}$ & 628.842 .000 & 677.625 .600 & 1.098.046.085 & 4.464 .817 .145 & 8.186 .840 .866 \\
\hline $\begin{array}{l}\text { Pelayanan } \\
\text { Persampahan }\end{array}$ & 511.350 .000 & 480.950 .000 & 365.825 .000 & 547.312 .500 & 303.250 .000 \\
\hline $\begin{array}{l}\text { Pelayanan } \\
\text { KTP \& Akta } \\
\text { Catatan Sipil }\end{array}$ & 1.165.458.000 & 1.376.544.000 & 781.050 .000 & 646.237.000 & 613.448.000 \\
\hline $\begin{array}{l}\text { Parkir Di Tepi } \\
\text { Jalan Umum }\end{array}$ & 223.129.000 & 259.849 .900 & 299.800 .500 & 526.157.500 & 700.816 .600 \\
\hline $\begin{array}{l}\text { Pengujian } \\
\text { Kendaraan } \\
\text { bermotor }\end{array}$ & 556.452 .800 & 580.651 .500 & 684.497 .500 & 691.800 .500 & 771.241.800 \\
\hline PHB/Askes & 480.227 .000 & 634.690.000 & 904.281 .524 & 1.257.366.440 & 1.122 .754 .948 \\
\hline $\begin{array}{l}\text { Izin Usaha } \\
\text { Jasa } \\
\text { Konstruksi }\end{array}$ & 133.000.000 & 151.300 .000 & 189.800 .000 & 219.850.000 & 191.600 .000 \\
\hline Tot a l & 2.534.166.258 & 2.786.443.544 & 3.226.352.570 & 8.353.541.085 & 11.889.952.214 \\
\hline
\end{tabular}

Sumber : Buku APBD Pemerintah Kota Kupang 2009 - 2013

Data pada tabel di atas menunjukkan bahwa, sumbangan retribusi pelayanan parkir di tepi jalan umum sebesar 1,13\% (2009); 1,07\% (2010); 1,08\% (2011); 1,59\% (2012) dan $1,70 \%$ (2013) terhadap total penerimaan retribusi jasa umum. Pada tahun 2012 - 2013, sumbangan retribusi parkir di tepi jalan umum meningkat cukup pesat jika dibandingkan dengan tahun - tahun sebelumnya. Hal ini berkaitan dengan jumlah kendaraan bermotor yang semakin meningkat. Target penerimaan retribusi parkir di tepi jalan umum tahun 2013 sebesar Rp. 640.000.000,- ternyata realisasinya sebesar $\quad 700.816 .600,-$ $(109,50 \%)$ atau bertambah sebesar Rp. 60.816.600,-

\section{Perkembangan Kontribusi Retribusi} Parkir Di Tepi Jalan Umum Terhadap Total PAD, Retribusi Daerah Dan Retribusi Jasa Umum Tahun 2009 - 2013

Data perkembangan kontribusi retribusi parkir di tepi jalan umum terhadap total penerimaan PAD, Retribusi Daerah dan Retribusi Jasa Umum periode tahun 2009 - 2013 dilihat pada tabel berikut : 


\section{JURNAL NOMINAL / VOLUME III NOMOR 1 / TAHUN 2014}

Tabel. 4

Data Perkembangan Peranan Retribusi Parkir Di Tepi Jalan Umum Terhadap Total Penerimaan PAD, Retribusi Daerah dan Retribusi Jasa Umum Tahun 2009 - 2013

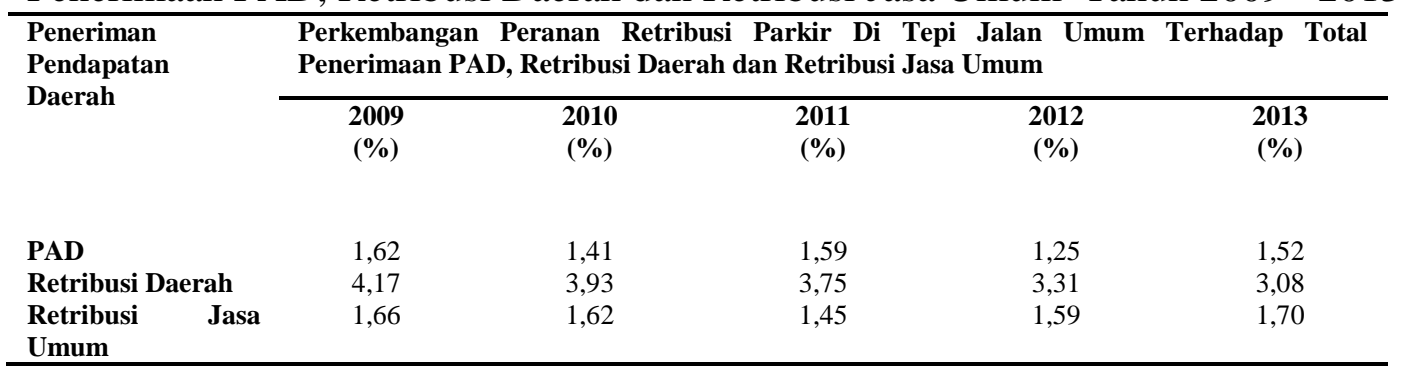

Sumber : Buku Perhitungan APBD Kota Kupang. 2009 - 2013 (Data diolah)

terakhir (2009 - 2013), kontribusi retribusi

Peranan retribusi parkir di tepi jalan umum terhadap total PAD tahun 2009 sebesar $1,62 \%$ dan menurun terus hingga tahun 2013 sebesar 1,52\%. Selanjutnya sumbangan retribusi parkir di tepi jalan umum terhadap total penerimaan retribusi daerah, pada tahun 2009 sebesar 4,17\% dan menurun menjadi 3,08\% pada tahun 2013 . Sedangkan sumbangan retribusi parkir di tepi jalan umum terhadap total penerimaan retribusi jasa umum sebesar 1,66\% tahun 2009 dan menurun terus sampai tahun 2012 dan tahun 2013 meningkat menjadi 1,70\%.

Faktor - Faktor Penyebab Rendahnya Kontribusi Retribusi Pelayanan Parkir Di Tepi Jalan Umum Terhadap Pendapatan Asli Daerah Kota Kupang

Temuan penelitian memperlihatkan bahwa peranan retribusi parkir di tepi jalan umum terhadap total PAD tahun 2009 sebesar $1,62 \%$ dan menurun menjadi 1,41\% (2010); kemudian naik menjadi 1,59\% (2011); lalu menurun menjadi 1,25\% (2012) dan naik lagi menjadi 1,52\%. pada tahun 2013. Rata - rata selama lima tahun parkir di tepi jalan umum terhadap PAD sebesar $1,48 \%$ per - tahun. Fakta ini menunjukkan bahwa, kontribusi retribusi parkir di tepi jalan umum terhadap pembentukan PAD pemerintah Kota Kupang relatif kecil. Berbagai fakta yang di sebutkan di atas, menunjukkan bahwa pemanfaatan potensi parkir di tepi jalan umum belum optimal. Menyadari arti pentingnya retribusi daerah khususnya retribusi parkir dalam memberikan kontribusi terhadap PAD serta potensi retribusi parkir sebagai sumber keuangan daerah, maka perlu dianalisis faktor - faktor penyebab rendahnya kontribusi retribusi pelayanan Parkir di tepi jalan umum terhadap Pendapatan Asli Daerah Kota Kupang

Proses implementasi Peraturan Daerah No.15 Tahun 2011 tentu dipengaruhi oleh faktor - faktor tertentu, dimana faktor faktor tersebut bisa saja menyebabkan terjadinya kegagalan dan atau keberhasilan didalam proses implementasinya dilapangan. Dalam kajian ini, penulis 


\section{JURNAL NOMINAL / VOLUME III NOMOR 1 / TAHUN 2014}

mencoba mengkaji faktor - faktor yang mempengaruhinya berdasarkan teori Meter and Horn serta Grindle. Mereka menjelaskan bahwa, faktor yang mempengaruhi keberhasilan implementasi kebijakan pada dasarnya dapat dilihat dari tiga faktor, yaitu faktor kebijakan itu sendiri, faktor lembaga (instansi pelaksana) dan faktor lingkungan.

\section{Faktor Kebijakan}

Penyusunan suatu kebijakan publik jelas ada tujuan dan manfaat tertentu terutama dalam menyelesaikan permasalahan yang menjadi isu strategis di daerah. Penerbitan Peraturan Daerah Nomor 15 Tahun 2011 juga memiliki tujuan dan manfaat yang jelas, yakni sebagai upaya menjawab kebutuhan daerah akan penerimaan daerah berupa PAD. Oleh karenanya, tujuan diterbitkannya Peraturan Daerah Nomor 15 Tahun 2011 ini seyogianya adalah untuk memberikan kontribusi yang optimal bagi penerimaan retribusi daerah di Kota Kupang.

Analisis aspek Rule berupa Perda No.15 Tahun 2011 diketahui bahwa; pada isi perda khususnya Bab I : Kebijakan Umum Pasal 1; tidak memuat secara lengkap penjelasan - penjelasan yang terkait dengan objek pungutan retribusi. Menurut Peneliti harus dimasukan penjelasan tentang : jalan umum; parkir; tempat parkir; tempat parkir insidental; parkir umum tetap; pengelola parkir; dan petugas parkir, agar tidak terjadi kerancuan. Pada Bab VIII Tentang Tata Cara Pemungutan Retribusi Pasal 12 ayat (1) disebutkan bahwa, pemungutan retribusi dilarang diborongkan. Faktanya pungutan retribusi telah diborongkan kepada pihak lain yakni pengelola parkir melalui proses tender. Alasan lembaga pelaksana peraturan, membuka lapangan kerja kepada masyarakat. Kalau demikian, maka ayat (1) pasal 12 perda tersebut harus di revisi, menyesuaikan dengan fakta yang terjadi. Isi Perda ini juga tidak memasukkan Bab yang mengatur tentang Pengelolaan Parkir serta Hak dan Kewajiban setiap aktor (pelaksana aturan; pengelola parkir, petugas parkir dan pengguna jasa parkir). Akibatnya dalam pelaksanaan pemungutan retribusi parkir dilapangan menimbulkan perilaku bermasalah dari para aktor dan berdampak pada penerimaan retribusi parkir yang tidak signifikan.

2. Faktor Lembaga Atau Instansi Pelaksana Pendelegasian wewenang dan tanggung jawab dalam mengimplementasikan Peraturan Daerah Nomor 15 Tahun 2011 kepada SKPD Perhubungan memang sudah tepat, namun kesiapan lembaga akan SDM yang akan melakukan pengelolaan implementasi Peraturan Daerah Nomor 15 Tahun 2011 belum optimal. SDM yang berperan sebagai implementor peraturan daerah ini harus memilki kejujuran, keterbukaan dan integritas dalam 


\section{JURNAL NOMINAL / VOLUME III NOMOR 1 / TAHUN 2014}

bekerja. Begitupun dengan mitra instansi pelaksana yaitu pengelola parkir dan juru pungut parkir, harus memiliki integritas yang baik dalam bekerja.

Dalam implementasi Peraturan Daerah No.15 tahun 2011, kepatuhan birokrasi yang disoroti adalah Pertama; kepatuhan dalam penetapan harga retribusi parkir untuk tiap lokasi parkir yang akan ditenderkan. Ada terdapat kelemahan dalam penentuan nilai kontrak pada setiap lokasi parkir dimana harga yang ditetapkan hanya berdasarkan pengamatan petugas pendata dari Dinas Perhubungan setempat, sehingga hal ini tidak menggambarkan potensi parkir yang sesungguhnya, akibatnya penetapan nilai kontrak tidak sesuai dengan nilai potensi parkir dan berdampak pada penerimaan retribusi parkir secara keseluruhan. Seharusnya, perkiraan potensi parkir dilakukan melalui survei yang dilakukan oleh pemerintah bekerjasama dengan akademisi, pengelola parkir dan petugas parkir.

Mengutip hasil penelitian yang dilakukan oleh Balitbang Kota Kupang (2013) tentang Potensi Pendapatan Asli Daerah Melalui Penerimaan Retribusi Parkir Di Kota Kupang menginformasikan bahwa; potensi penerimaan retribusi parkir di tepi jalan sebesar Rp. 3.117.900.000,- (Tiga Milyard Seratus Tujuh Belas Juta Sembilan Ratus Ribu Rupiah). Sedangkan potensi penerimaan parkir khusus sebesar Rp.
287.000.000,- (Dua Ratus Delapan Puluh Juta Rupiah). Total potensi retribusi parkir sebesar Rp.3.404.900.000,- (Tiga Milyard Empatima Ratus Empat Juta Sembilan Ratus Ribu Rupiah). Jika angka potensi penerimaan ini dibandingkan dengan target penerimaan retribusi parkir yang di tetapkan oleh pemerintah tahun 2013 sebesar Rp. 680.000.000,- terdapat perbedaan yang sangat besar.

\section{Faktor Lingkungan}

Keberhasilan implementasi suatu kebijakan selain dipengaruhi oleh variabel isi kebijakan ( content of policy) juga variabel lingkungan implementasi (context of implementation), sebagaimana yang dikemukakan dalam Teori Merilee $S$. Grindle. Variabel lingkungan kebijakan mencakup : (1) seberapa besar kekuasaan, kepentingan, dan strategi yang dimiliki oleh para aktor yang terlibat dalam implementasi kebijakan; (2) karakteristik institusi dan rejim yang sedang berkuasa; (3) tingkat kepatuhan dan responsivitas kelompok sasaran $^{13}$. Dari ketiga faktor yang termasuk kedalam variabel lingkungan kebijakan, peneliti menganalisis lebih mendalam tentang faktor ketiga, yakni ; faktor kepatuhan dan responsivitas kelompok sasaran sehubungan dengan implementasi Perda Nomor 15 Tahun 2011

\footnotetext{
${ }^{13}$ Merilee S. Grindle 1980, dalam AG Subarsono,
} Analisis Kebijakan Publik, Op.Cit. hlm. 93 


\section{JURNAL NOMINAL / VOLUME III NOMOR 1 / TAHUN 2014}

Pada prinsipnya, setiap aktor mempunyai keinginan untuk berperilaku sesuai peraturan yang ada, namun oleh karena Perda No.15 Tahun 2011 hanya menitikberatkan pada hal pungutan retribusi parkir yang harus ditaati oleh para aktor tanpa aturan lainnya yang berhubungan dengan hak dan kewajiban semua aktor, maka terjadi pelanggaran - pelanggaran oleh para aktor.

Sesuai dengan ketentuan, petugas parkir harus menggunakan tanda pengenal atau kartu identitas diri berupa; rompi bernomor urut yang bertuliskan Juru Parkir Kota Kupang pada punggung belakang serta celana panjang berwarna gelap dan sepatu kets, juga peluit, dan lampu senter jalan, Namun ketentuan ini juga belum dijalankan secara baik masih dijumpai petugas parkir yang tidak berseragam, hal ini menimbulkan persepsi negatif terhadap juru parkir karena dianggap petugas parkir liar. Ketentuan lainnya yakni, setiap pengelola harus memasang papan pengumuman petunjuk area parkir (Khusus/Tepi Jalan Umum) ukuran 40 x $40 \mathrm{~cm}$ isinya : Judul Parkir, Nama Pengelola Parkir, Nilai Retribusi Kendaraan), Namun hal ini juga tidak dilaksanakan oleh setiap pengelola parkir. Padahal melalui papan pengumuman ini, para wajib retribusi parkir dapat mengetahui secara transparan nama pengelola dan besaran tarif retribusi yang resmi.
Dalam rangka memecahkan perilaku yang menyimpang dari para aktor pemegang peran baik itu lembaga pelaksana aturan, pengelola parkir, petugas parkir dan pengguna jasa parkir sehubungan dengan aktivitas pelayanan perparkiran di Kota Kupang, maka solusinya adalah perlu merevisi Perda Nomor 15 tahun 2011 dimana bab tentang Pengelolaan Parkir dan Bab tentang hak dan kewajiban setiap aktor harus tersirat dalam perda tersebut.

\section{SIMPULAN DAN SARAN}

\section{Simpulan}

1. Kontribusi retribusi parkir di tepi jalan umum terhadap total PAD tahun 2009 sebesar 1,62 \%, tahun 2010 sebesar $1,41 \%$, tahun 2011 sebesar 1,59\%, tahun 2012 sebesar $1,25 \%$ dan tahun 2013 sebesar $1,52 \%$. Selanjutnya sumbangan retribusi parkir di tepi jalan umum terhadap total penerimaan retribusi daerah, pada tahun 2009 sebesar 4,17\% dan menurun menjadi 3,08\% pada tahun 2013. Sedangkan sumbangan retribusi parkir di tepi jalan umum terhadap total penerimaan retribusi jasa umum sebesar $1,66 \%$ tahun 2009 dan menurun terus sampai tahun 2012 dan 2013 meningkat menjadi $1,70 \%$.

2. Perda No.15 Tahun 2011 tentang Retribusi Pelayanan Parkir Di Tepi Jalan, telah di implementasikan kepada masyarakat, namun implementasi Perda 


\section{JURNAL NOMINAL / VOLUME III NOMOR 1 / TAHUN 2014}

tersebut ternyata belum dapat menyumbang bagi PAD Kota Kupang secara signifikan, padahal potensi parkir yang ada sangat besar yakni sebesar Rp.3.404.900.000,- $\quad$ (Tiga Milyard Empatima Ratus Empat Juta Sembilan Ratus Ribu Rupiah sedangkan target penerimaan parkir tahun 2013 hanya sebesar Rp. 680.000.000,- (Enam Ratus Delapan Puluh Juta Rupiah). Faktor faktor yang di duga berpengaruh terhadap kecilnya angka penerimaan retribusi parkir di tepi jalan adalah sebagai berikut :

a. Faktor kebijakan yaituPRule itu sendiri, dimana isi perda parkir nomor 15 tahun 2011 bertentangan dengan kenyataan di lapangan terutama pada Pasal 12 ayat (1). Selain itu, tidak ada ketentuan yang mengatur tentang hal pengelolaan parkir dan ketentuan tentang hak dan kewajiban para aktor.

b. Faktor instansi pelaksana, juga sebagai salah satu faktor pemicu rendahnya penerimaan retribusi parkir di tepi jalan, dimana penentuan harga parkir pada setiap lokasi parkir hanya berdasarkan pengamatan petugas pendata pada Dinas Perhubungan, hal ini tidak menggambarkan potensi parkir yang sesungguhnya

sehingga menguntungkan pihak pengelola parkir.

c. Faktor lingkungan; dalam praktik di lapangan, banyak terjadi pelanggaran - pelanggaran yang dilakukan oleh para pemegang peran, baik pelaksana peraturan, pengelola parkir, petugas parkir dan pengguna jasa parkir terutama yang berkaitan dengan sistem pengelolaan parkir yang kurang akuntable serta pelanggaran hak dan kewajiban setiap aktor akibat dari hal tersebut belum tersirat dalam perda tersebut.

\section{Saran}

a. Hasil survey menunjukkan bahwa; potensi penerimaan retribusi parkir di tepi jalan sebesar Rp. 3.117.900.000,(Tiga Milyard Seratus Tujuh Belas Juta Sembilan Ratus Ribu Rupiah). Sedangkan potensi penerimaan parkir khusus sebesar Rp. 287.000.000,- (Dua Ratus Delapan Puluh Juta Rupiah). Total potensi retribusi parkir sebesar Rp.3.404.900.000,- $\quad$ (Tiga Milyard Empat Ratus Empat Juta Sembilan Ratus Ribu Rupiah).. Disarankan data hasil survei tersebut dapat dijadikan pedoman dalam proses penetapan harga tender pengelola parkir pada tahun berikutnya.

b. Kebijakan lainnya dapat dilakukan dengan merubah sistem pemungutan 


\section{JURNAL NOMINAL / VOLUME III NOMOR 1 / TAHUN 2014}

retribusi parkir yang berjalan sekarang dengan sistem pemungutan retribusi yang baru, yakni pembayaran retribusi parkir secara tahunan. Mekanismenya sebagai berikut; setiap kendaraan yang masa berlaku STNK habis dan mengurus perpanjangan STNK diwajibkan membayar retribusi parkir sesuai dengan nilai tarif yang ditetapkan dalam Peraturan Daerah.Tugas dari pengelola parkir dan petugas parkir fokus pada memberikan pelayanan kepada pengguna jasa parkir dengan baik, menjaga keamanan, ketertiban, keindahan dan kelancaran arus lalu lintas dikawasan lokasi parkir yang menjadi kewenangannya, dengan mendapatkan upah dari pemerintah perbulan. Apabila paradigma sistem penagihan retribusi parkir ini diterapkan, maka akan terjadi lonjakan penerimaan retribusi parkir yang sangat pesat. Jumlah kendaraan roda dua, empat, enam, dan diatasnya posisi tahun 2011 terdapat sebanyak 127.024 unit, kalau setiap unit dikenakan tarif parkir sebesar Rp. 100.000,- per unit/tahun, maka akan diperoleh penerimaan retribusi sebesar Rp. 12.702.400.000,-(Duabelas Milyart Tujuh Ratus Dua Juta Empat Rupiah). Jika dibandingkan dengan target penerimaan retribusi parkir tahun 2013 sebesar Rp. 680.000.000,- (Enam Ratus Delapan Puluh Juta Rupiah), maka terjadi lonjakan penerimaan retribusi parkir sebanyak $1.868 \%$. Untuk itu, Pemerintah Kota Kupang harus bekerjasama dengan Instansi terkait. Sedangkan bagi kendaraan bermotor yang berasal dari kabupaten lain dan negara lain yang masuk kewilayah Kota Kupang, diharuskan membeli voucher harian yang disiapkan petugas pada loket pintu gerbang yang berlokasi di batas wilayah antara Kota Kupang dan Kabupaten Kupang di Jalan Timor Raya.

c. Perda No. 15 Tahun 2011 tentang Retribusi Pelayanan Parkir Di Tepi Jalan Umum harus direvisi, dimana Bab I tentang Kebijakan Umum Pasal 1 harus dimasukan penjelasan tentang : jalan umum; parkir; tempat parkir; tempat parkir insidental; parkir umum tetap; pengelola parkir; dan petugas parkir, agar tidak terjadi kerancuan. Pada Bab VIII Tentang Tata Cara Pemungutan Retribusi Pasal 12 ayat (1) harus di revisi, menyesuaikan dengan fakta yang terjadi. Juga perlu dimasukkan Bab yang mengatur tentang Pengelolaan Parkir serta Hak dan Kewajiban setiap aktor (pelaksana aturan; pengelola parkir, petugas parkir dan pengguna jasa parkir.

\section{DAFTAR PUSTAKA}

Aslofa, Burhan , 2010, Metode Penelitian, Jakarta ;Rineka Cipta. 
JURNAL NOMINAL / VOLUME III NOMOR 1 / TAHUN 2014

Darise Nurlan, 2012, Pengelolaan

Perubahan Masyarakat yang

Keuangan Pada Satuan Kerja

Demokratis, Edisi Terjemahan : ELIPS

Perangkat Daerah (SKPD), Jakarta :

Omsset.

Mardiasmo, 2004, Otonomi \& Manajemen

Keuangan Daerah, Yogyakarta : Andi Offset.

Kansil, S.T. Christine, 2009, Pengantar

Hukum Indonesia, Jakarta : Sinar

Grafika.

Riwu Kaho Josef, 1998, Prospek Otonomi

Daerah Di Negara Republik

Indonesia,Jakarta : Raja Grafindo

Persada.

M.P Marsuki, 2010, Penelitian Hukum,

Jakarta : Fajar Interpratama Offset.

Purwanto Agus Erwan. Ph D. Sulistyastuti

Ratih Dyah. M.Si, 2012, Implementasi

Kebijakan Publik Beserta Konsep dan

Aplikasinya Di Indonesia, Yogyakarta

Grava Media.

Seidman, Ann et all, 2001, Penyusunan

Rancangan Undang - Undang Dalam 